\title{
The crystal structure of naujakasite,
}

\author{
a double sheet silicate
}

\author{
Riccardo Basso, Alberto Dal Negro, Antonio Della Giusta \\ and Luciano Ungaretti
}

\begin{abstract}
The crystal structure of naujakasite from Tuperssuatsiait has been determined by $\mathrm{X}$-ray data from four-circle computer controlled Philips PW 1100 diffractometer (Mo K $\alpha$ radiation).

Naujakasite crystallizes in the space group $C 2 / m$ with cell dimensions $a=15.025(1), b=$ 7.991(2), $c=10.486(1) \AA, \beta=113^{\circ} 40^{\prime}\left(5^{\prime}\right)$; the structural formula is $\mathrm{Na}_{6} \mathrm{FeAl}_{4} \mathrm{Si}_{8} \mathrm{O}_{26}, Z=2$.

The structure has been solved by Patterson methods and refined by full matrix least-squares method to $R_{w}=0.027$.

Naujakasite is a sheet silicate with double layers of tetrahedra perpendicular to the $c$ direction. All the oxygen atoms of the structure are shared between two tetrahedra except one that interrupts the three-dimensional linking. Each single layer is formed by rings of six tetrahedra and the linkage between two single layers gives rise to rings of four and six tetrahedra. Out of the three independent tetrahedral sites present in the structure one is occupied by silicon and the other two by $(0.5 \mathrm{Si}+$ $0.5 \mathrm{Al})$.

The Na-O polyhedra (quite irregular) and the $\mathrm{Fe}-\mathrm{O}$ polyhedron (a tetragonal bipyramid) are all linked together forming a three-dimensional framework in which all the oxygen atoms of the structure are involved.
\end{abstract}

\section{Introduction}

The crystal structure analysis of naujakasite has been undertaken on the basis of the exhaustive description made by Petersen (1967) with essentially three aims: (1) the determination of the space group out of the three $(\mathrm{C} 2, \mathrm{Cm}, \mathrm{C2} / \mathrm{m})$ consistent with the systematic absences; (2) the fitting of the chemical analysis to the structural results in order to settle some points of interest like the presence or the lack of water molecules in the structure, the $\mathrm{FeO} / \mathrm{Fe}_{2} \mathrm{O}_{3}$ ratio and the amount of cation diadochy that were slightly doubtful owing to the great difficulty in obtaining sufficiently pure material; (3) the relationships between naujakasite and other silicate minerals.

\section{Experimental procedure}

The structural formula of naujakasite, the cell dimensions and other related data are given in table 1 .

Cell dimensions were re-determined by least-squares from $20 \mathrm{high}$-angle reflections carefully centered with a General Electric four circle diffractometer using $\mathrm{Cu} \mathrm{K} \alpha$ radiation $(\lambda=1.54051 \AA)$. They are in excellent agreement with the earlier determination made by Petersen (1967) using Guinier photographs. From the three space groups consistent with the systematic absences, the centrosymmetric one $(C 2 / m)$ was chosen 
according to statistical averages and distribution of the normalized structure factors.

The calculated density (2.714) is slightly different from the density measured by Petersen (2.622) suspending the mineral in heavy liquids; the difference is probably due to the thin layers of air and/or analcite along the basal cleavage, as pointed out by Petersen himself.

For the structure determination a single platy crystal $(0.22 \times 0.16 \times 0.03 \mathrm{~mm})$ of naujakasite from Tuperssuatsiait in the Ilimaussaq intrusion, South Greenland, has been used. Intensities were measured by $\omega$-scans with a Philips PW 1100 computercontrolled four circle diffractometer, using Mo $\mathrm{K} \alpha$ radiation $(\lambda=0.71069 \AA)$ monochromatized with a graphite crystal. The rate of scanning was $0.064 \% \mathrm{sec}$ and the scan range was $2^{\circ}$. The background was measured, on either side of the scan range, for a time $T$ according to the equation: $T=\frac{1}{2} T_{\text {scan }} . \sqrt{ } I_{b c k} / I_{i n t}$, where $T_{\text {scan }}$ is the total scantime, $I_{b c k}$ is the mean of two preliminary background measurements of $5 \mathrm{sec}$. at each side of the scan interval in which the total number of counts $\left(I_{i n t}\right)$ was memorized. When the condition $I_{t o p}-2 \sqrt{ } I_{t o p}<I_{b c k}$ happened during the scan the reflection was skipped; at the end of the refinement these weak reflections were re-introduced with $F_{0}=0$.

Three standard reflections were measured every hour to check the crystal alignment during the data collection. No significant variation in their intensity was observed, and no automatic re-orientation of the crystal occurred. All reflections in the hemisphere of reciprocal space $\pm \mathrm{h}, \pm \mathrm{k},+1$ were collected out to a $\vartheta$ angle of $30^{\circ} .1809$ independent reflections were inspected; 212 out of these were skipped and 1496, with $I>\sigma(I)$, were used in the refinement.

Net intensities and their standard deviations were calculated according to the formulae:
(1) $I=C-T_{c} / 2 T_{b}\left(B_{1}+B_{2}\right)$;
(2) $\sigma(I)=\sqrt{ }\left[C+\left(T_{c} / 2 T_{b}\right)^{2}\left(B_{1}+B_{2}\right)\right]$

where $C$ is the total number of counts recorded during the scan time $T_{c}$ and $B_{1}, B_{2}$ are the background counts, each measured for a time $T_{b}$. When the two background intensities were different in such a way that $\left(B_{1}+B_{2}\right)$ was less than $\left(B_{1}-B_{2}\right)^{2} / 4$, the former quantity was replaced by the latter in the formula (2). Intensities of equivalent reflections and those measured more than once were averaged. The intensities were corrected for Lorentz and polarization effects, but not for absorption $\left(\mu=14.8 \mathrm{~cm}^{-1}\right)$.

The weighting scheme used throughout the refinement gave zero weight if $F^{2}<$ $\sigma\left(F^{2}\right)$ and $w=4 F^{2} / \sigma^{2}\left(F^{2}\right)$ if $F^{2} \geqslant \sigma\left(F^{2}\right)$.

\section{Structure determination and refinement}

The data were placed on an approximately absolute scale and $|E|$ values were calculated using Wilson's (1942) method. The statistical averages and distribution of the normalized structure factors are in very good agreement with the theoretical 
Table 1. Cell dimensions of naujakasite and other related data

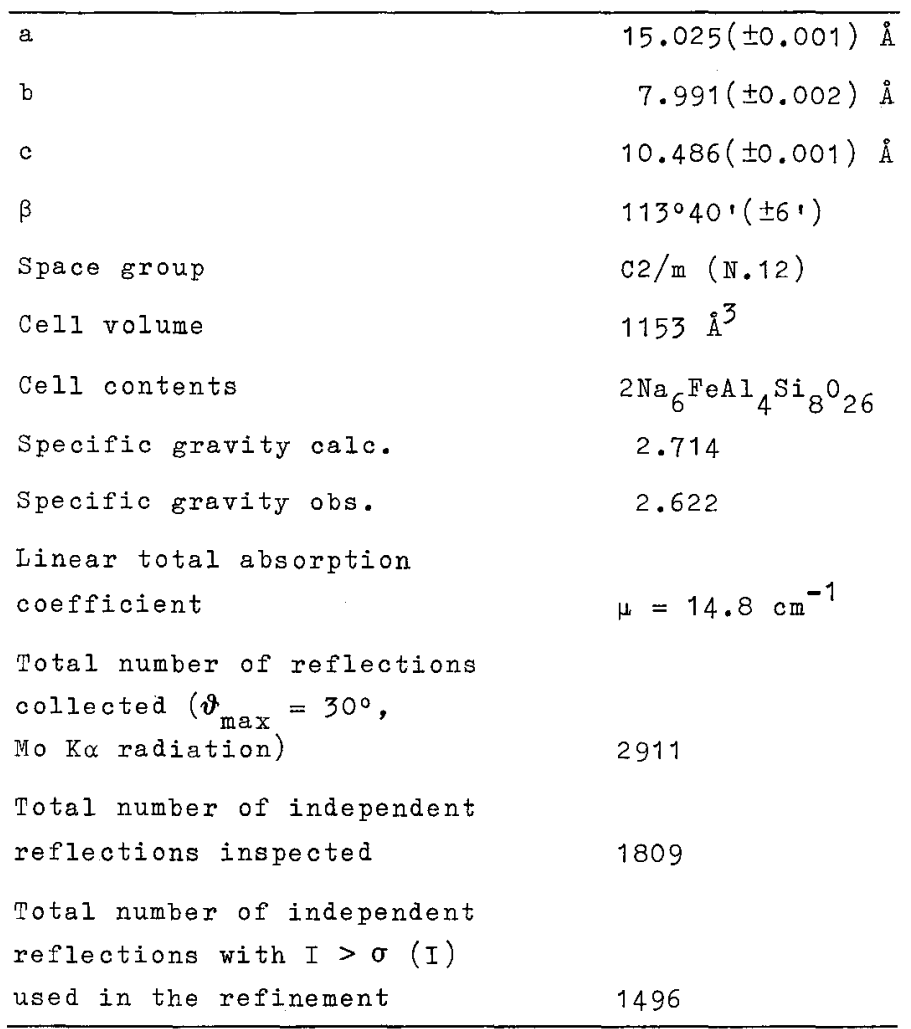

values for centrosymmetric distribution of atoms in the unit cell (Karle et al., 1965); therefore the space group $C 2 / m$ was chosen and afterwards confirmed by the results of the crystal structure determination.

The structure was solved by inspection of the three-dimensional Patterson map that gave the position of the iron atom and of three complete Si-O tetrahedra. A threedimensional Fourier map computed with the coordinates of these atoms allowed to locate the sodium atoms. Since no other prominent peaks were evident in the Fourier maps, it was decided to refine the coordinates of the atoms found so far, even if one water molecule was expected to be present, according to the chemical analyses made by C. R. Dethlefsen and by E. I. Semenov (Petersen, 1967). Several determinations of the weight percent of $\mathrm{H}_{2} \mathrm{O}$ have been made also in our laboratory, but the results were always doubtful due to the difficulty in obtaining a sufficiently pure material.

The isotropic refinement of the structural model obtained from the Fourier maps, considering at first the tetrahedral positions to be fully occupied by silicon, converged to $R_{w}=\sqrt{\Sigma \mathrm{w}\left(\left|F_{0}\right|-|-| F_{c} \mid\right)^{2} / \Sigma \mathrm{w}\left|F_{0}\right|^{2}}=0.08$, using the atomic scattering factors listed by Hanson et al., (1964). 
It was possible to deduce, from the oxygen-tetrahedral cation distances, that one tetrahedral position, $T(1)$, was fully occupied by silicon, while the other two positions, $T(2)$ and $T(3)$, were $(0.5 \mathrm{Si}+0.5 \mathrm{Al})$, corresponding to an overall amount of aluminium that is in good agreement with the chemical formula tentatively proposed by Petersen. According to this conclusion the atomic scattering curve for the two tetrahedral cations, $T(2)$ and $T(3)$, was obtained by averaging the values of $(\mathrm{Si}+\mathrm{Al}) / 2$. One additional isotropic least-square cycle converged to $R_{w}=0.068$.

At this point anisotropic thermal factors were included in the refinement and the multipliers of the cations were allowed to vary, in order to check the occupancy and the isomorphic substitution of the cations. The anisotropic refinement converged to $R_{w}=0.027$ without significant variation from complete occupancy of the sodium and iron atoms and with a full confirmation of the $\mathrm{Si}, \mathrm{Al}$ distribution used throughout the anisotropic refinement. The conventional $R$ factor, at the end of the refinement, was $R=0.041$ and the final parameter shifts were less than $0.01 \sigma$.

The secondary extinction was negligible, so no extinction factor was taken into account.

A three-dimensional difference Fourier synthesis was carried out which did not show any significant peak.

It is possible to conclude, from the results of the refinement, that naujakasite has the following chemical formula:

$\mathrm{Na}_{6} \mathrm{FeAl}_{4} \mathrm{Si}_{8} \mathrm{O}_{26}, Z=2$

Table 2. Idealized chemical analysis corresponding to the structural formula compared with the chemical analysis

\begin{tabular}{|c|c|c|c|c|}
\hline & \multicolumn{2}{|c|}{$\begin{array}{c}\text { Chemical analysis calculated } \\
\text { from structural formula }\end{array}$} & \multicolumn{2}{|c|}{ Wet chemical analysist } \\
\hline & Weight per cent & $\begin{array}{l}\text { Number of cations } \\
\text { in the unit cell }\end{array}$ & Weight per cent* & $\begin{array}{l}\text { Number of cations } \\
\text { in the unit cell }\end{array}$ \\
\hline $\mathrm{SiO}_{2}$ & 51.00 & 16 & 52.11 & 16.26 \\
\hline $\mathrm{TiO}_{2}$ & & & 0.03 & $0.01\}_{7.82}$ \\
\hline $\mathrm{A}_{2} \mathrm{O}_{3}$ & 21.64 & 8 & 21.24 & $7.81 J 10.0 \mathrm{c}$ \\
\hline$F \in 0$ & 7.63 & 2 & 5.70 & 1.49 \\
\hline Mno & & & 1.13 & $0.30\} 1.89$ \\
\hline $\mathrm{CaO}$ & & & 0.31 & 0.10 \\
\hline $\mathrm{Na}_{2} \mathrm{O}$ & 19.73 & 12 & 18.90 & $11.43\}$ \\
\hline $\mathrm{K}_{2} \mathrm{O}$ & & & 0.51 & $0.20^{\prime}$ \\
\hline $\mathrm{P}_{2} \mathrm{O}_{5}$ & - & - & 0.07 & 0.02 \\
\hline & 100.00 & 38 & 100.00 & \\
\hline
\end{tabular}

†Analyst: Ib Sørensen, GGU.

*Weight per cent recalculated on the basis that iron contents are entirely present as $\mathrm{FeO}$. 
without significant diadochy.

The idealized chemical analysis corresponding to the structural formula, apart from small isomorphic substitution of the cations (that, however, should be less than $1 \%$ in weight), is reported in table 2 , where it is compared with the chemical analysis made by I. Sørensen and recalculated disregarding the results of the thermogravimetric analysis. It clearly appears that the chemical results are substantially in good agreement with the structural analysis, with only a few small differences. The assumption that trivalent iron hardly can be present is confirmed by the facts that the tetrahedral sites are fully occupied by the amount of silicon and aluminium resulted from the chemical analysis, and that the iron on the origin, for the electrostatic neutrality of the structure, must be divalent.

The final fractional atomic coordinates and the anisotropic thermal parameters, as well as their standard deviations, are listed in table 3 and in table 4 . The analysis of the anisotropic thermal parameters is reported in table 5 .

Observed and calculated structure factors may be requested directly from the authors.

Table 3. Fractional atomic coordinates with their standard deviations in parentheses and equivalent isotropic temperature factors after Hamilton (1959)

\begin{tabular}{|c|c|c|c|c|}
\hline A tom & $x / a$ & $y / b$ & $z / c$ & $\mathrm{~B}_{\mathrm{H}} \AA^{2}$ \\
\hline $\mathrm{Fe}$ & 0.0000 & 0.0000 & 0.0000 & 1.01 \\
\hline$T(1)$ & $0.1505(1)$ & $0.3081(1)$ & $0.1315(1)$ & 0.65 \\
\hline$T(2)$ & $0.0584(1)$ & $0.1953(1)$ & $0.3415(1)$ & 0.81 \\
\hline$T(3)$ & $0.1463(1)$ & $0.3014(1)$ & $0.6507(1)$ & 0.73 \\
\hline$O(1)$ & $0.1010(1)$ & $0.1789(3)$ & $0.0102(2)$ & 1.64 \\
\hline $0(2)$ & $0.2681(1)$ & $0.2937(3)$ & $0.2103(2)$ & 1.22 \\
\hline $0(3)$ & $0.1070(1)$ & $0.3120(3)$ & $0.2509(2)$ & 1.22 \\
\hline$O(4)$ & $0.1318(1)$ & 0.5000 & $0.0647(3)$ & 1.09 \\
\hline $0(5)$ & $0.1393(1)$ & $0.1973(3)$ & $0.5071(2)$ & 1.72 \\
\hline$o(6)$ & $0.0360(2)$ & 0.0000 & $0.2759(3)$ & 1.82 \\
\hline$o(7)$ & $0.0445(1)$ & $0.2932(3)$ & $0.6771(2)$ & 1.26 \\
\hline$o(8)$ & $0.1769(2)$ & 0.5000 & $0.6338(3)$ & 1.60 \\
\hline $\mathrm{Na}(1)$ & $0.2299(1)$ & 0.5000 & $0.4403(2)$ & 1.60 \\
\hline $\mathrm{Na}(2)$ & $0.3430(1)$ & 0.5000 & $0.1126(2)$ & 1.85 \\
\hline $\mathrm{Na}(3)$ & $0.4643(1)$ & 0.0000 & $0.1650(2)$ & 1.88 \\
\hline
\end{tabular}


16

Table 4. Final anisotropic thermal parameters $\left(\times 10^{4}\right) *$ and their standard deviations in parentheses

\begin{tabular}{|c|c|c|c|c|c|c|}
\hline Atom & $\beta_{11}$ & $\beta_{22}$ & $\beta_{33}$ & $\beta_{12}$ & $\beta_{13}$ & $\beta_{23}$ \\
\hline $\mathrm{Fe}$ & $8(1)$ & $11(1)$ & $59(1)$ & 0 & $12(1)$ & 0 \\
\hline$T(1)$ & $7(1)$ & $17(1)$ & $26(1)$ & $-1(1)$ & $5(1)$ & $-3(1)$ \\
\hline$T(2)$ & $8(9)$ & $28(1)$ & $30(1)$ & $-1(1)$ & $7(1)$ & $-8(1)$ \\
\hline$T(3)$ & $7(1)$ & $22(1)$ & $28(1)$ & $-2(1)$ & $5(1)$ & $-3(1)$ \\
\hline$O(1)$ & $18(1)$ & $59(4)$ & $61(3)$ & $-20(2)$ & $19(2)$ & $-37(3)$ \\
\hline$o(2)$ & $11(1)$ & $47(4)$ & $37(2)$ & $2(2)$ & $4(1)$ & $12(3)$ \\
\hline $0(3)$ & $18(1)$ & $36(3)$ & $46(3)$ & $-3(2)$ & $18(1)$ & $-1(3)$ \\
\hline$O(4)$ & $15(2)$ & $40(5)$ & $25(3)$ & 0 & $4(2)$ & 0 \\
\hline $0(5)$ & $14(1)$ & $61(4)$ & $65(3)$ & $2(2)$ & $11(2)$ & $-33(3)$ \\
\hline $0(6)$ & $19(2)$ & $73(6)$ & $44(4)$ & 0 & $1(2)$ & 0 \\
\hline$o(7)$ & $15(1)$ & $42(4)$ & $45(3)$ & $-4(2)$ & $12(1)$ & $-1(3)$ \\
\hline$o(8)$ & $15(2)$ & $70(6)$ & $57(4)$ & 0 & $16(2)$ & 0 \\
\hline $\mathrm{Na}(1)$ & $16(1)$ & $59(3)$ & $50(2)$ & 0 & $8(1)$ & 0 \\
\hline $\mathrm{Na}(2)$ & $30(1)$ & $49(3)$ & $75(3)$ & 0 & $34(1)$ & 0 \\
\hline $\mathrm{Na}(3)$ & $20(1)$ & 104 (4) & $32(2)$ & 0 & $4(1)$ & 0 \\
\hline
\end{tabular}


Table 5. Analysis of the anisotropic thermal parameters*

\begin{tabular}{|c|c|c|c|c|}
\hline A tom & r.m.s. & $\mathrm{U}_{i}{ }^{\mathrm{a}}$ & $U_{i} b$ & $\mathrm{U}_{i} \mathrm{c}$ \\
\hline $\mathrm{Fe}$ & $\begin{array}{l}0.059(4) \\
0.081 \\
0.168(3)\end{array}$ & $\begin{array}{r}90 \\
180 \\
90\end{array}$ & $\begin{array}{r}8 \\
90 \\
105\end{array}$ & $\begin{array}{r}81 \\
90 \\
164\end{array}$ \\
\hline$T(1)$ & $\begin{array}{ll}0.072 & (3) \\
0.081 & (2) \\
0.113 & (2)\end{array}$ & $\begin{array}{r}105 \\
160 \\
94\end{array}$ & $\begin{array}{r}20 \\
108 \\
102\end{array}$ & $\begin{array}{r}76 \\
81 \\
166\end{array}$ \\
\hline$T(2)$ & $\begin{array}{l}0.085(2) \\
0.087 \\
0.126(3)\end{array}$ & $\begin{array}{r}158 \\
104 \\
82\end{array}$ & $\begin{array}{r}109 \\
29 \\
62\end{array}$ & $\begin{array}{r}81 \\
65 \\
151\end{array}$ \\
\hline $\mathrm{T}(3)$ & $\begin{array}{l}0.079(3) \\
0.089 \\
0.117(3)\end{array}$ & $\begin{array}{r}132 \\
133 \\
89\end{array}$ & $\begin{array}{r}45 \\
135 \\
102\end{array}$ & $\begin{array}{r}75 \\
81 \\
167\end{array}$ \\
\hline$o(1)$ & $\begin{array}{l}0.079(7) \\
0.126(5) \\
0.200(4)\end{array}$ & $\begin{array}{l}119 \\
138 \\
102\end{array}$ & $\begin{array}{r}31 \\
107 \\
136\end{array}$ & $\begin{array}{r}99 \\
53 \\
130\end{array}$ \\
\hline$O(2)$ & $\begin{array}{ll}0.098 & (6) \\
0.117 & (5) \\
0.151 & (4)\end{array}$ & $\begin{array}{r}128 \\
63 \\
109\end{array}$ & $\begin{array}{r}47 \\
44 \\
114\end{array}$ & $\begin{array}{r}66 \\
121 \\
148\end{array}$ \\
\hline$O(3)$ & $\begin{array}{l}0.099(6) \\
0.115 \\
0.153(5)\end{array}$ & $\begin{array}{r}135 \\
131 \\
60\end{array}$ & $\begin{array}{r}53 \\
137 \\
122\end{array}$ & $\begin{array}{r}112 \\
84 \\
133\end{array}$ \\
\hline$O(4)$ & $\begin{array}{l}0.104 \\
0.114(8) \\
0.133\end{array}$ & $\begin{array}{r}108 \\
90 \\
137\end{array}$ & $\begin{array}{r}90 \\
0 \\
90\end{array}$ & $\begin{array}{r}161 \\
90 \\
47\end{array}$ \\
\hline$O(5)$ & $\begin{array}{l}0.095(6) \\
0.122(5) \\
0.204\end{array}(4)$ & $\begin{array}{r}126 \\
41 \\
59\end{array}$ & $\begin{array}{l}42 \\
68 \\
77\end{array}$ & $\begin{array}{r}72 \\
56 \\
146\end{array}$ \\
\hline$o(6)$ & $\begin{array}{l}0.120(7) \\
0.154(6) \\
0.176(6)\end{array}$ & $\begin{array}{r}127 \\
90 \\
119\end{array}$ & $\begin{array}{r}90 \\
0 \\
90\end{array}$ & $\begin{array}{r}143 \\
90 \\
29\end{array}$ \\
\hline$O(7)$ & $\begin{array}{l}0.105 \\
0.126 \\
0.145\end{array}\left(\begin{array}{l}6 \\
0.14)\end{array}\right.$ & $\begin{array}{r}136 \\
134 \\
75\end{array}$ & $\begin{array}{r}46 \\
136 \\
106\end{array}$ & $\begin{array}{r}88 \\
88 \\
157\end{array}$ \\
\hline $0(8)$ & $\begin{array}{l}0.108(7) \\
0.150(6) \\
0.163(6)\end{array}$ & $\begin{array}{r}180 \\
90 \\
66\end{array}$ & $\begin{array}{r}90 \\
0 \\
90\end{array}$ & $\begin{array}{r}90 \\
90 \\
156\end{array}$ \\
\hline $\mathrm{Na}(1)$ & $\begin{array}{l}0.125(4) \\
0.138(4) \\
0.161(3)\end{array}$ & $\begin{array}{r}150 \\
90 \\
95\end{array}$ & $\begin{array}{r}90 \\
0 \\
90\end{array}$ & $\begin{array}{r}60 \\
90 \\
174\end{array}$ \\
\hline $\mathrm{Na}(2)$ & $\begin{array}{l}0.120(4) \\
0.126(4) \\
0.199(3)\end{array}$ & $\begin{array}{r}154 \\
90 \\
40\end{array}$ & $\begin{array}{r}90 \\
0 \\
90\end{array}$ & $\begin{array}{r}115 \\
90 \\
130\end{array}$ \\
\hline $\mathrm{Na}(3)$ & $\begin{array}{l}0.116(4) \\
0.155(4) \\
0.183(3)\end{array}$ & $\begin{array}{r}110 \\
90 \\
135\end{array}$ & $\begin{array}{r}20 \\
90 \\
134\end{array}$ & $\begin{array}{r}90 \\
180 \\
90\end{array}$ \\
\hline
\end{tabular}

* Root mean squares thermal vibrations along the ellipsoid axes $(\AA)$, with their standard deviations in parentheses, and angles (in degrees) between the crystallographic axes and the principal axes $\left(U_{i}\right)$ of the vibration ellipsoids. 


\section{Description and discussion of the structure}

Naujakasite is a sheet silicate characterized by the presence of a double layer of tetrahedra perpendicular to the $c$ direction. In figure 1 the projection of the double layer down the $b$ direction is shown. Each single layer (fig. 2) is formed by three different rings of six tetrahedra; the rings are built up by two mirror-related wollastonitelike chains (i.e. with repeat unit of three tetrahedra) which are connected through the $\mathrm{O}(4), \mathrm{O}(6), \mathrm{O}(8)$ oxygen atoms. Two centrosymmetric layers are linked to each other through the oxygen atom $O(5)$ to form the double sheet; in this way all the oxygen atoms are shared except $\mathrm{O}(1)$ that interrupts the linkage of the tetrahedra along the $c$ direction.

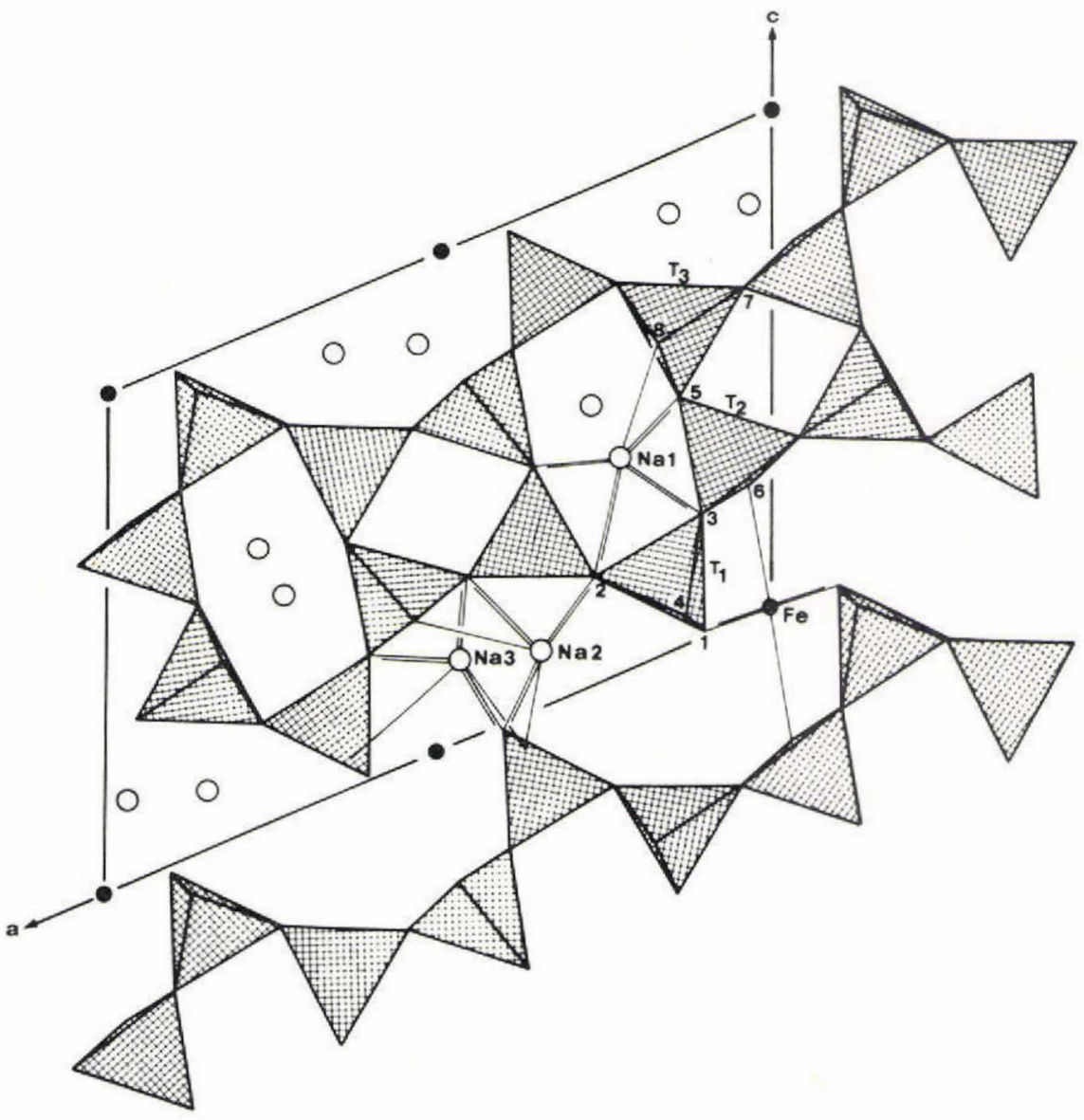

Fig. 1. The double layer of tetrahedra of naujakasite projected along [010]. The cations are connected by thin lines with the oxygen atoms of the tetrahedral framework; double lines are referred to a pair of equivalent, mirror-related oxygen atoms. 


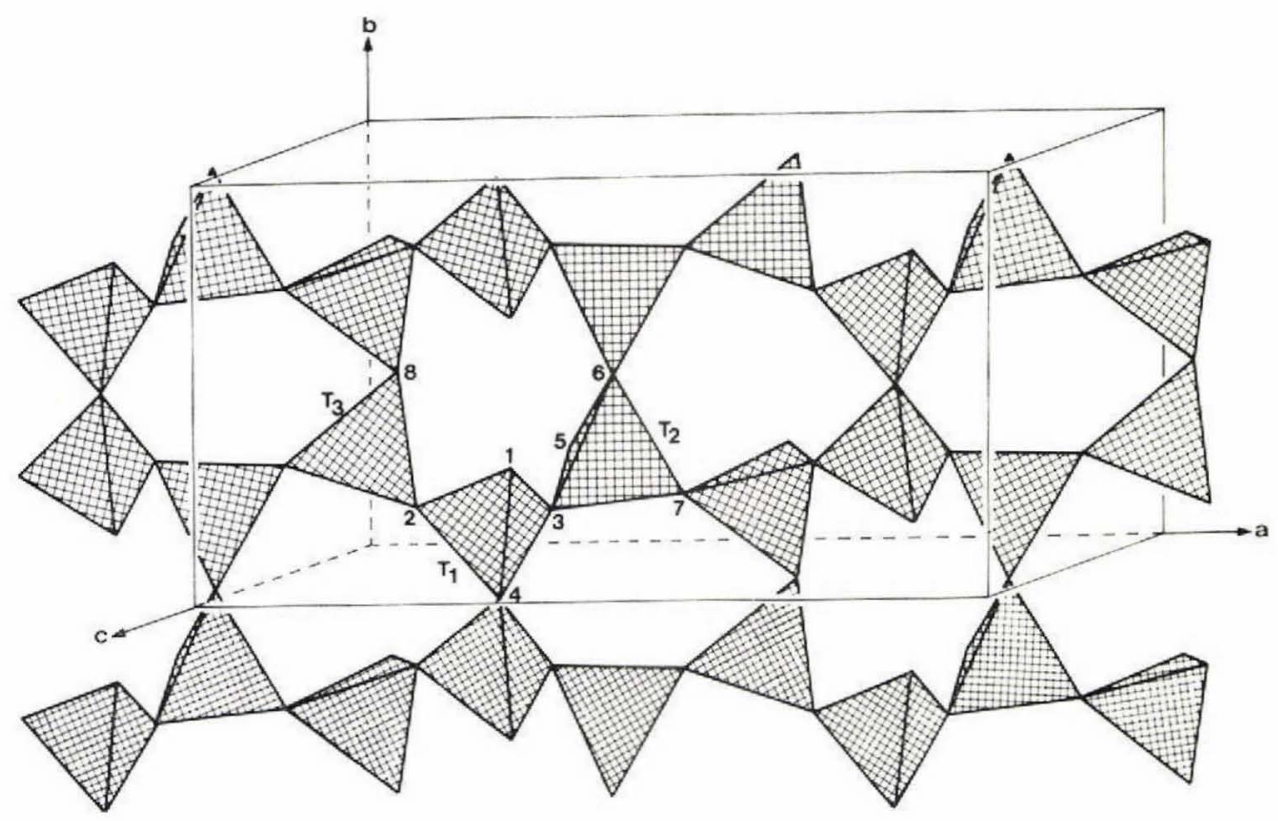

Fig. 2. Clinographic projection of a single layer of tetrahedra of naujakasite.

The linkage between the two single layers gives rise to rings of four and six tetrahedra (fig. 3) which form infinite channels running along the $b$ direction. The $\mathrm{Na}(1)$ atoms have places in the channels formed by the six-membered rings; $\mathrm{Na}(2), \mathrm{Na}(3)$ and $\mathrm{Fe}$ atoms can be considered as interlayer cations connecting double layers of tetrahedra along the $c$ direction.

From these findings the connection of the $\{001\}$ mica-like cleavage with the double sheet structure of naujakasite is obvious.

The iron atom has a six-fold coordination, which corresponds to a fairly regular tetragonal bipyramid with two centrosymmetric $\mathrm{O}(6)$ atoms in the apical positions. It is worth while pointing out the unusually long Fe-O(6) distance (2.722 $\AA$ ), which cannot be neglected due to charge balance considerations (see later).

The three independent sodium atoms $\mathrm{Na}(1), \mathrm{Na}(2), \mathrm{Na}(3)$ form, with the oxygen atoms of the tetrahedral framework, irregular polyhedra with respectively $5+4$, $5+3,5+3$ coordination number (see table 6 ). The $\mathrm{Na}-\mathrm{O}$ and $\mathrm{Fe}-\mathrm{O}$ polyhedra are all linked together in a rather complicated way forming a three-dimensional framework in which all the oxygen atoms of the structure are involved.

The naujakasite structure is the sixth sheet silicate with double layers of tetrahedra known so far. In macdonaldite (Cannillo et al., 1968), in delhayelite (Cannillo et al., 1970) and in carletonite (Chao, 1972) each single layer is built up with rings of four and eight tetrahedra; in latiumite structure (Cannillo et al., 1973) the layers are made 


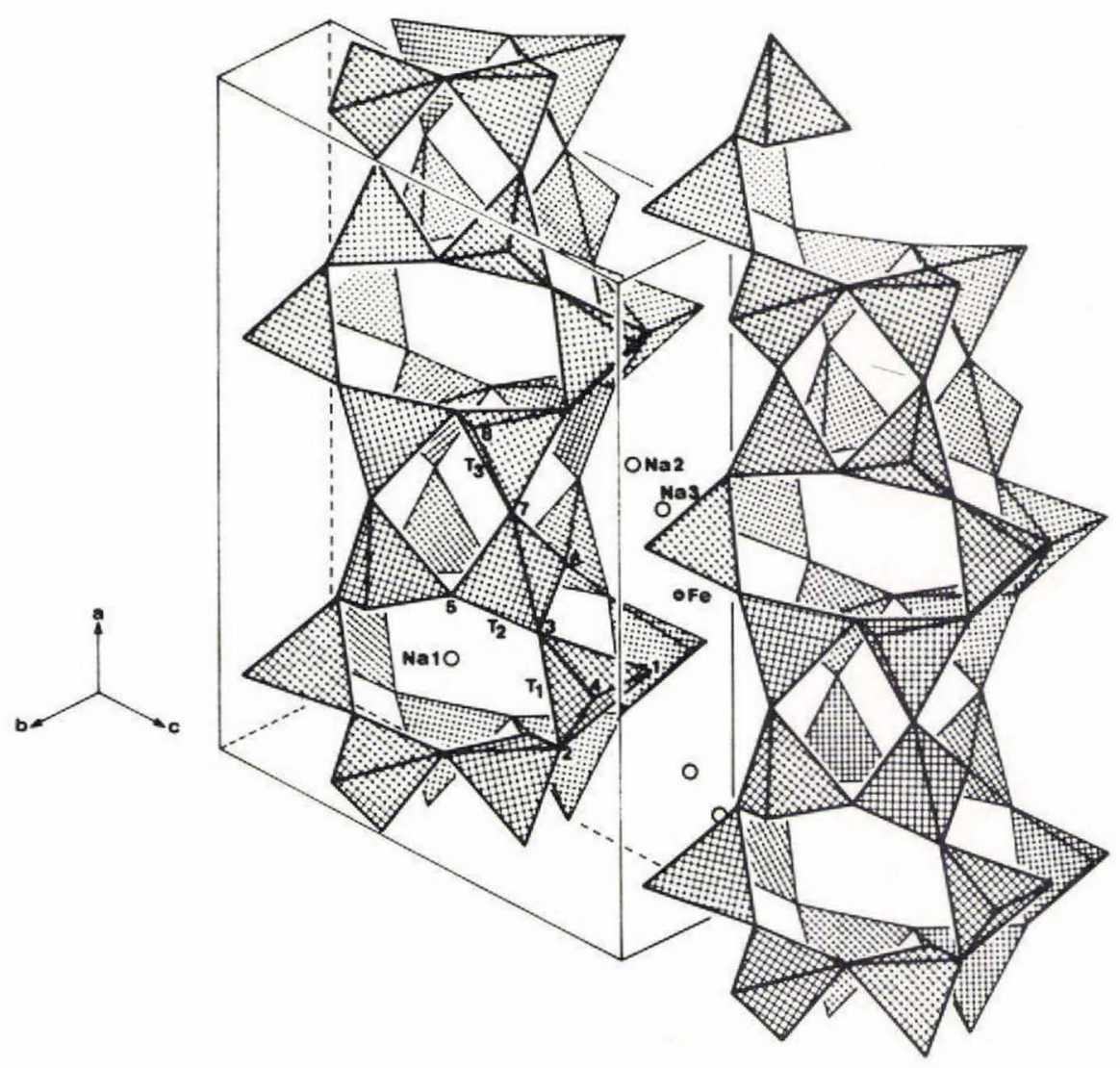

Fig. 3. Clinographic projection of the crystal structure of naujakasite, showing two complete double layers of tetrahedra and the interlayer cations.

with rings of six and eight tetrahedra. Major similarities occur between naujakasite and hexagonal $\mathrm{CaAl}_{2} \mathrm{Si}_{2} \mathrm{O}_{8}$ (Takeuchi \& Donnay, 1959) in which each single layer is formed with rings of six tetrahedra too. However in hexagonal $\mathrm{CaAl}_{2} \mathrm{Si}_{2} \mathrm{O}_{8}$ each tetrahedron shares all its corners with neighbouring tetrahedra thus making the ratio $\mathrm{O} /(\mathrm{Si}, \mathrm{Al})=2$, which corresponds to the Zoltai's (1960) sharing coefficient $c=2$ or to the modified (Coda, 1969) sharing coefficient $C=4$; in naujakasite the corresponding figures are: $\mathrm{O} /(\mathrm{Si}, \mathrm{Al})=2.167, c=1.917$ and $C=3.667$. In this way in hexagonal $\mathrm{CaAl}_{2} \mathrm{Si}_{2} \mathrm{O}_{8}$ each tetrahedron of a single sheet shares its apical oxygen with the apical oxygen of another sheet, thus forming the double layer of tetrahedra; in naujakasite only four oxygen atoms, $\mathrm{O}(5)$, in each ring of six tetrahedra, are shared with the adjacent sheet to form the double layer, leaving unshared the remaining two oxygen atoms, $\mathrm{O}(1)$. 
Table 6. Interatomic distances $(A)$ with their standard deviations in parentheses

\begin{tabular}{|c|c|c|}
\hline Atoms & Bond lengths & Symmetry operation \\
\hline $\begin{array}{r}T(1)-O(1) \\
-O(2) \\
-O(3) \\
-O(4)\end{array}$ & $\begin{array}{l}1.574(2) \\
1.626(2) \\
1.629(2) \\
1.662(2)\end{array}$ & \\
\hline Average & 1.623 & \\
\hline $\begin{array}{r}\mathrm{T}(2)-0(3) \\
-0(5) \\
-0(6) \\
-0(7)\end{array}$ & $\begin{array}{l}1.692(2) \\
1.673(2) \\
1.684(2) \\
1.673(2)\end{array}$ & $-x, y, 1-z$ \\
\hline Average & 1.680 & \\
\hline $\begin{array}{c}\mathrm{T}(3)-0(2) \\
-0(5) \\
-0(7) \\
-0(8)\end{array}$ & $\begin{array}{l}1.689(2) \\
1.687(2) \\
1.660(2) \\
1.681(2)\end{array}$ & $1 / 2-x, 1 / 2-y, 1-z$ \\
\hline Average & 1.679 & \\
\hline $\begin{array}{r}\mathrm{Fe}-0(1) \\
-0(6)\end{array}$ & $\begin{aligned} * * 2.056 & (2) \\
* 2.722 & (3)\end{aligned}$ & \\
\hline $\begin{aligned} & \mathrm{Na}(1)-\mathrm{O}(2) \\
&-\mathrm{O}(3) \\
&-\mathrm{O}(5) \\
&-\mathrm{O}(5) \\
&-\mathrm{O}(8)\end{aligned}$ & $\begin{array}{l}* 3.158(3) \\
* 2.582(3) \\
* 2.993(3) \\
* 2.405(3) \\
2.459(3)\end{array}$ & $1 / 2-x, 1 / 2+y, 1-z$ \\
\hline $\begin{array}{c}\mathrm{Na}(2)-O(1) \\
-O(2) \\
-O(4) \\
-O(6) \\
-O(7)\end{array}$ & $\begin{array}{r}* 2.298(3) \\
* 2.441(3) \\
3.006(3) \\
2.713(3) \\
* 3.196(3)\end{array}$ & $\begin{array}{l}1 / 2-x, 1 / 2+y,-z \\
1 / 2+x, 1 / 2+y, \quad z \\
1 / 2-x, 1 / 2+y, 1-z\end{array}$ \\
\hline $\begin{array}{c}\mathrm{Na}(3)-O(1) \\
-O(3) \\
-O(4) \\
-O(4) \cdots \\
-O(7) \cdot\end{array}$ & $\begin{array}{r}* 3.078(3) \\
* 2.472(3) \\
2.258(3) \\
3.093(3) \\
* 2.380(3)\end{array}$ & $\begin{array}{l}1 / 2-x, 1 / 2-y,-z \\
1 / 2+x, 1 / 2-y, \quad z \\
1 / 2-x, 1 / 2+y,-z \\
1 / 2-x, 1 / 2-y, 1-z\end{array}$ \\
\hline
\end{tabular}

A sign ' is used to distinguish equivalent atoms. The distances preceded by one asterisk occur twice; those preceded by two asterisks occur four times 
Table 7. Angles with their standard deviations in parentheses

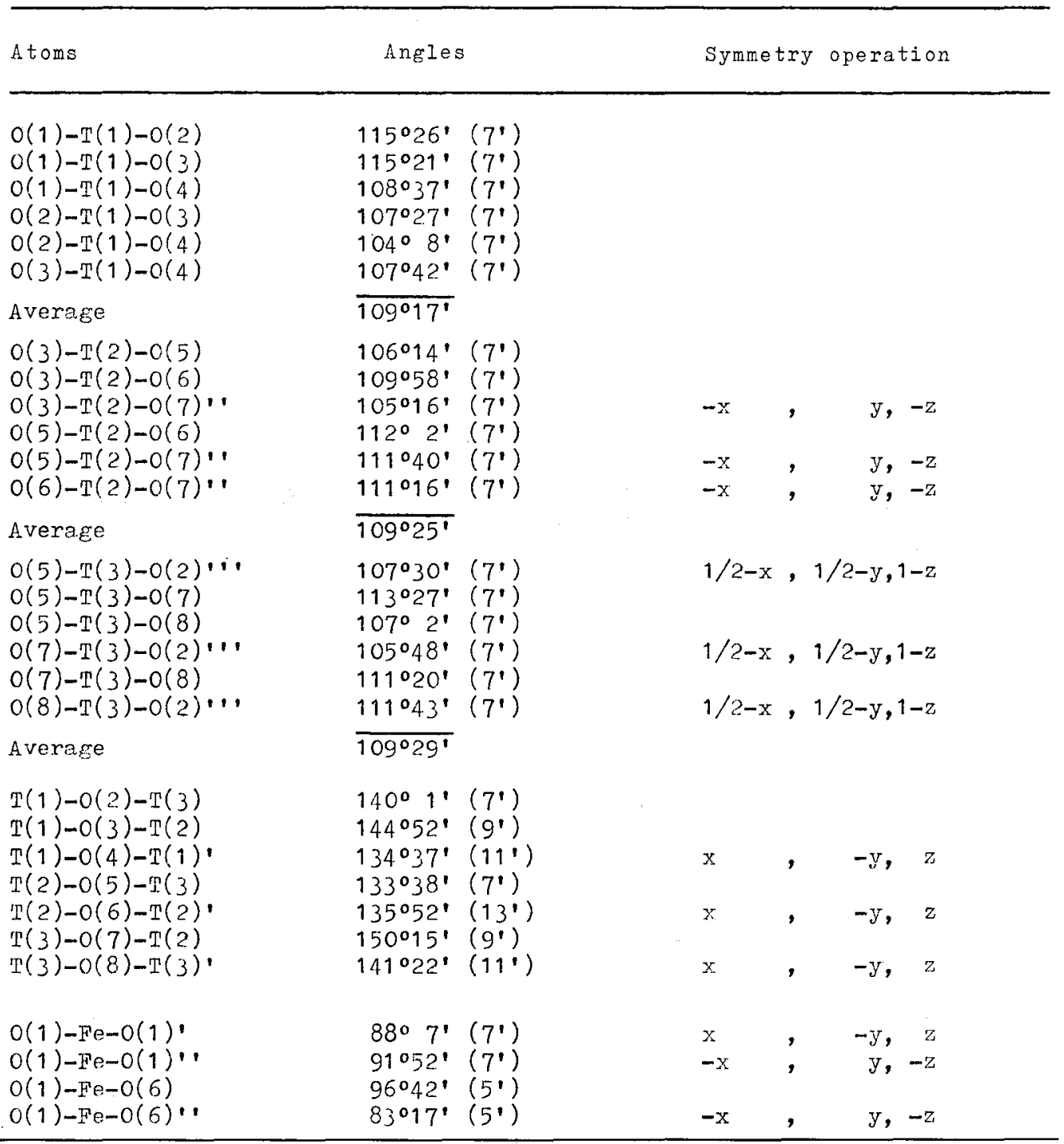

As pointed out before, the distribution of $\mathrm{Si}$ and $\mathrm{Al}$ atoms in the three independent tetrahedral sites has been determined on the basis of the relationship between T-O distances (table 6) and Al contents given by the chemical analysis. The T(2)-O and $\mathrm{T}(3)-\mathrm{O}$ mean bond lengths are in perfect agreement with a half and half $\mathrm{Si}, \mathrm{Al}$ distribution.

The $T(1)-O(1)$ short bond length and the relatively high $\mathrm{O}(1)-\mathrm{T}(1)-\mathrm{O}$ angles (table 7) are those expected from an unshared oxygen atom. 
Table 8. Charge balance

\begin{tabular}{|c|c|c|c|c|c|c|c|c|}
\hline & $T(1)$ & $\mathbb{T}(2)$ & $T(3)$ & $\mathrm{Na}(1)$ & $\mathrm{Na}(2)$ & $\mathrm{Na}(3)$ & $\mathrm{Fe}$ & \\
\hline$O(1)$ & 1.15 & & & & 0.23 & 0.05 & 0.45 & 1.88 \\
\hline$O(2)$ & 0.98 & & 0.85 & 0.03 & 0.16 & & & 2.02 \\
\hline $0(3)$ & 0.98 & 0.84 & & 0.13 & & 0.14 & & 2.09 \\
\hline$O(\dot{4})$ & 0.89 & & & & 0.05 & $\begin{array}{l}0.23+ \\
0.03 \\
\end{array}$ & & 2.09 \\
\hline $0(5)$ & & 0.89 & 0.86 & $\begin{array}{l}0.19+ \\
0.06\end{array}$ & & & & 2.00 \\
\hline$O(6)$ & & 0.88 & & & 0.11 & & 0.10 & 1.97 \\
\hline$O(7)$ & & 0.89 & 0.91 & & 0.03 & 0.18 & & 2.01 \\
\hline $0(8)$ & & & 0.88 & 0.18 & & & & 1.94 \\
\hline & 4.00 & 3.50 & 3.50 & 1.00 & 1.00 & 1.00 & 2.00 & 16.00 \\
\hline
\end{tabular}

On the basis of the suggestions given by Brown \& Shannon (1973), bond-strength bond-length relationships have been derived by using the formula $s=s_{0}\left(R / R_{0}\right)^{-\mathrm{N}}$ and by requiring that the sum of the bond strengths around the cations be equal to their valences. The results shown in table 8 are considered very satisfactory and provide an additional evidence of the correctness of both the crystal structure and the chemical formula proposed for naujakasite. The best charge balance has been achieved taking into account the contribution of all the $\mathrm{Na}-\mathrm{O}$ and $\mathrm{Fe}-\mathrm{O}$ distances listed in table 6.

The thermal situation is in perfect agreement with the structural results; the major part of the atoms have the maximum thermal displacement (table 5) along the $c$ direction, according to the mica-like $\{001\}$ cleavage observed.

\section{Acknowledgements}

The authors wish to thank Professor H. Sørensen, Institute of Petrology of the University of Copenhagen, and O. V. Petersen, Mineralogical Museum of the University of Copenhagen, for providing the material and for fruitful discussions of some crucial points of this work. 


\section{References}

Brown, J. D. \& Shannon, R. D. 1973: Empirical bond-strength - bond-length curves for oxides. Acta Cryst. A 29, 266-282.

Cannillo, E., Rossi, G. \& Ungaretti, L. 1968: The crystal structure of macdonaldite. Rend. Acc. Naz. Lincei, Classe Sci. Mat. Fis. Nat. Serie 8, 45, 399-414.

Cannillo, E., Rossi, G. \& Ungaretti, L. 1970: The crystal structure of delhayelite. Rend. Soc. Miner. Petrol. Ital. 26, 63-75.

Cannillo, E., Dal Negro, A. \& Rossi, G. 1973: The crystal structure of latiumite, a new type of sheet silicate. Amer. Miner. 58, 466-470.

Chao, G. Y. 1972: The crystal structure of carletonite $\mathrm{KNa}_{4} \mathrm{Ca}_{4} \mathrm{Si}_{8} \mathrm{O}_{18}\left(\mathrm{CO}_{3}\right)_{4}(\mathrm{~F}, \mathrm{OH}) . \mathrm{H}_{2} \mathrm{O}$, a double sheet silicate. Amer. Miner. 57, 765-778.

Coda, A. 1969: La classificazione di alcuni silicati secondo Zoltai. Rend. Soc. Miner. Petrol. Ital. 25, 195-226.

Hamilton, W. C. 1959: On the isotropic temperature factor equivalent to a given anisotropic temperature factor. Acta Cryst. 12, 609-610.

Hanson, H. P., Herman, F., Lea, J. D. \& Skilman, S. 1964: HFS atomic scattering factors. Acta Cryst. 17, 1040-1044.

Karle, I. L., Dragonette, K. S. \& Brenner, S. A. 1965: The crystal and molecular structure of the serotonin-creatinine sulphate complex. Acta Cryst. 19, 713-716.

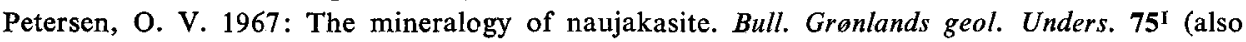
Meddr Gronland 181, 6) $18 \mathrm{pp}$.

Takeuchi, Y. \& Donnay, G. 1959: The crystal structure of hexagonal $\mathrm{CaAl}_{2} \mathrm{Si}_{2} \mathrm{O}_{8}$. Acta Cryst. 12, 465-470.

Wilson, A. J. C. 1942: Determination of absolute from relative X-ray intensity data. Nature, Lond. 150, 151-152.

Zoltai, T. 1960: Classification of silicates and other minerals with tetrahedral structures. Amer. Miner. 45, 960-973.

R. Basso and A. Della Giusta,

Istituto di Mineralogia dell' Università

Corso Europa

I-16132-Genova,

Italy.
A. Dal Negro and L. Ungaretti, Centro di studio del C.N.R. per la cristallografia strutturale, Istituto di Mineralogia dell' Università Via A. Bassi n. 4, I-27100-Pavia, Italy. 